\title{
Increasing students' skills in operations management classes: Cumbuca Method as teaching-learning strategy
}

\section{A influência do Método da Cumbuca no estímulo à leitura dos estudantes de engenharia: análise da aplicação na disciplina de gestão de produção}

\author{
Jorge Muniz Junior ${ }^{1}$ \\ José de Souza Rodrigues ${ }^{2}$ \\ Alice Assis $^{3}$ \\ Francisca Clara de Paula Oliveira ${ }^{4}$ \\ Bruno Chaves Franco ${ }^{5}$ \\ Fabricio Gomes Maciel ${ }^{1,6}$
}

\begin{abstract}
This paper analyses the use of the Cumbuca Method as a teaching strategy to develop reading skills in engineering students. Despite their importance, reading skills are little stimulated in engineering undergraduate courses. Teamwork, communication, organization and exposure of ideas, time management are also important skills to new employees. The Cumbuca Method was created to disseminate quality concepts among company employees, by discussing text related to a given topic of interest. This analysis is based on a qualitative approach involving a sample of 200 engineering undergraduates from Operations Management discipline at a public University in the State of Sao Paulo, Brazil. The results showed that the use of this teaching strategy inducted improvements to regular reading and debate among students.
\end{abstract}

Keywords: Reading; Operations management; Undergraduation; Teaching strategy.

Resumo: Este artigo analisa o uso do Método da Cumbuca como uma estratégia de ensino para desenvolver habilidade de leitura nos estudantes de engenharia. Independente da importância da sua importância, a habilidade de leitura é pouco estimulada nos cursos de graduação de engenharia. Trabalho em equipe, comunicação, organização na formulação de ideias, gestão de tempo são também habilidades importantes para novos empregados. O Método da Cumbuca foi criado para disseminar conceitos de qualidade entre empregados das empresas, pela discussãoo de textos relacionado a dado tópico de interesse. Esta análise é baseada em enfoque qualitativo envolvendo uma amostra de 200 graduandos de engenharia da disciplina de Gestão da Produção em uma Universidade Estadual Paulista, Brazil. Os resultados mostram que o uso desta estratégia de ensino induziu melhorias para leitura e debate entre os estudantes.

Palavras-chave: Leitura; Engenharia de produção; Graduação; Estratégia de ensino.

\footnotetext{
${ }^{1}$ Departamento de Produção, Faculdade de Engenharia de Guaratinguetá - FEG, Universidade Estadual Paulista - UNESP, Avenida Ariberto Pereira da Cunha, 333, Pedregulho, CEP 12516-410, Guaratinguetá, SP, Brazil, e-mail: jorgemuniz@feg.unesp.br

${ }^{2}$ Departamento de Engenharia de Produção, Faculdade de Engenharia de Bauru - FEB, Universidade Estadual Paulista - UNESP, Avenida Eng. Luiz Edmundo C. Coube 14-01, Vargem Limpa, CEP 17033-360, Bauru, SP, Brazil, e-mail: jsrod@feb.unesp.br

${ }^{3}$ Departamento de Física e Química, Faculdade de Engenharia de Guaratinguetá - FEG, Universidade Estadual Paulista - UNESP, Avenida Ariberto Pereira da Cunha, 333, Pedregulho, CEP 12516-410, Guaratinguetá, SP, Brazil, e-mail: alice@feg.unesp.br

${ }^{4}$ Departamento de Educação, Universidade Regional do Cariri - URCA, Rua Coronel Antônio Luiz, 1161, Pimenta, CEP 63100-000, Crato, CE, Brazil, e-mail: francisca.clara@urca.br

${ }^{5}$ Departamento de Produção, Faculdade de Engenharia de Bauru - FEB, Universidade Estadual Paulista - UNESP, Avenida Eng. Luiz Edmundo C. Coube 14-01, Vargem Limpa, CEP 17033-360, Bauru, SP, Brazil, e-mail: francosjc@hotmail.com

${ }^{6}$ Escola de Engenharia de Lorena - EEL, Universidade de São Paulo - USP, Estrada Municipal do Campinho, s/n, CEP 12602-810, Lorena, SP, Brazil, e-mail: fabricio@feg.unesp.br
}

Received Jan. 30, 2014 - Accepted Sept. 21, 2015

Financial support: None. 


\section{Introduction}

This research explored the use of the Cumbuca Method, proposed by Campos (2004), as a teaching strategy to stimulate reading in the disciplines of industrial engineering in order to develop skills in the students. The Cumbuca Method, hereafter referred to as "Method", is based on the previous reading of papers to support the class and selection of a student to lead the discussion in the classroom. The question-research is: May this teaching method contribute to motivate engineering students to actively participate in the learning process?

Usually Brazilian Engineers are educated in technical courses based on traditional discursive classrooms. The Brazilian Engineering courses need significant changes to improve skills as teamwork, good communication, organizing and exposing ideas in public, and managing time. Communication skills go beyond training with a focus on the content approach (Lang et al., 1999). Besides add new technology-based contents to the Engineering curriculum there have not been any significant changes in its classes (Dym, 2004).

The research apply qualitative approach interviewing 200 engineering students from a public Higher Education Institute of Sao Paulo, Brazil. It is based on the students' perspective exposed to the Cumbuca Method in the discipline of Production Management during one year.

The research findings indicated that the use of the Cumbuca method contributes both to improving students' reading and debating skill. These findings may guide a teaching-learning strategy to engage student and it is aligned with Engineering Education area of the Brazilian Association of Production Engineering (ABEPRO), that seeks to create and investigate concepts, methods, procedures and techniques that may improve undergraduates learning for professional challenges.

The Engineering Teaching theoretical background is discussed in Section 2. The Cumbuca Method is described in Section 3. The research is detailed in Section 4 and Section 5 discusses the findings, indicating the main points regarding the application of the Method based on the students' perception. Section 6 records the Conclusion.

\section{What is required from $21^{\text {st }}$ century engineers?}

Professional skills as listening, message writing, team working, decision-making, problem solving, leadership, multidisciplinary perspective, negotiation, conflict resolution, goal setting, understanding of diversity and globalization are important for engineers career (Chubin et al., 2008; McMasters, 2006; Lamancusa et al., 2008). Evolving from a conventional resolution of technical problems to a non-technical approach in engaging students in proposing solutions to social problems, policy formulation and innovation in local, national and global contexts, including the negotiation process to implement the solutions (Zhou, 2012; Riley et al., 2000). It has always been expected that scientists and engineers have great technical skills to work at the academia or in the industry, including analytical and problem-solving skills (Hissey, 2000).

There is a generalized concern regarding the strengthening of skills involving the technical content of Engineering students. Lujan \& DiCarlo (2006) indicate that for a better understanding of the contents for students, it is important to reduce the amount of factual information and the passive format of the classes, as well as to encourage students to become active, autonomous and able to solve problems.

\section{How to encourage the development of communication skills in engineering students?}

Several studies (Pister, 1993; Lang et al., 1999; Sageev \& Romanowski, 2001) point out the reading, discussion and interpretation of texts as important skills for the professional profile of an Engineer. Reading not only generates knowledge and communication, but also it creates meaning for individuals (Larrosa, 2002 apud Delamaro et al., 2006).

The pedagogical practices in the fields of Humanities and Social Sciences of undergraduate schools tend to encourage students to have a greater participation in their learning activities and to reflect on them. However, the practices of the Natural Science and Engineering courses are commonly focused on technical operational methods, i.e., they tend to strengthen the posture of knowledge reproduction (Brint et al., 2008). In addition to that, engineering courses do not stimulate the development of skills associated with reading, writing, and discussing ideas among students.

Transformations in the Engineering area, reported by Lang et al. (1999) and Martin et al. (2005), are partly responsible for the rise of issues associated with the education of Engineers, such as the ability to work in teams, dealing with cultural and gender matters, with complex and interdisciplinary problems, and with a great volume of theories, norms and instruments, among others.

Learning should help students become active, independent, and able to solve problems. One way to contribute to this is to analyze the format of the classes. Most of the time, the monologue of the teacher predominates (Lujan \& DiCarlo, 2006) indicating the need to propose improvements to become more efficient and effective. 
Expose contents to students are not enough for effective learning, active processing and critical reception of information. Students should build their own understanding of knowledge, relationships, and procedures. Teachers can encourage the learning process through different teaching systems (Lujan \& DiCarlo, 2006). One learning strategy that can contribute to an engineering student is the discussion of technical texts in the classroom.

Qualified reading and discussion plays an important role in supporting the students to develop their individual skills to discuss ideas, to speak in public, to be concise and objective when communicating an idea in writing, orally and in the form of graphs, understanding what people say and learning collectively.

With respect to engineering students' learning, educators have emphasized the importance and need for "authentic learning activities" in which students can work with real-world problems (Brown et al., 1989 apud Hwang \& Chang, 2011). Montero \& González (2009) emphasize that learning involves the construction of knowledge, requiring from the students to actively seek to create meaning for their own experiences by relating new information to what they already know. Ellis et al. (2008) indicate that the factors related to the best learning performance in undergraduate students have two components:

- Students: what they do and how they think when working. Student activity is directly related to results from a learning point of view;

- Environmental/teaching: derived from indirect relationships with positive learning outcomes.

Ellis et al. (2008) present two forms of learning: the Deep form in which there is guidance for understanding, the creation of personal sense and active learning; and the Superficial form in which there is guidance for the memorization and reproduction of knowledge, sometimes accompanied by personal engagement and learning activities. Table 1 presents the relationship concerning the impacts of forms of learning according to Ellis et al. (2008) and Gibbs (1992 apud Kember et al., 2008).

Superficial approach tends to keep the student focused on the reproduction of knowledge, based on traditional performance evaluations, in which teacher direct energies to gather the greatest volume of contents for their students to learn the prescribed in the disciplines. The result is a strain on both sides. The students overloaded by work focused on memorizing and reproducing knowledge, and the teacher focused on the material preparation and correction of performance evaluations. Despite the overwork, the amount of time together, the teaching-learning process is tense, tiring and exhausting for both.

Brint et al. (2008, p. 389) discuss which fields of knowledge influence the teaching-learning process and the academic engagement of undergraduates. The fields of Social Sciences and Humanities stimulate interaction and debate, inducing students to contribute with new ideas. On the other hand, the fields of Natural Sciences and Engineering promote collaborative study and learning of technical skills. The comparison of the two cultures is presented in Table 2 and indicates that the difference between the fields requires distinct treatments for the development of skills.

The Accreditation Committee for Engineering and Technology (ABET) indicates some skills as being important for undergraduates: interpersonal communication, the execution of individual presentations, and the preparation of case studies (Dym, 2004; Mohan et al., 2010). It also adds skills such as:

- Teamwork, the development of creative thinking, awareness to self-criticism and commitment to self-directed learning. (Montero \& González, 2009, p. 214);

- Listening, building messages, making decisions, problem solving, leadership, multidisciplinary perspective, negotiation, conflict resolution, organizing goals, understanding diversity and globalization (Mohan et al., 2010).

Table 1. Impacts of forms of learning on teachers.

\begin{tabular}{cl}
\hline Forms of learning & \multicolumn{1}{c}{ Impacts } \\
\hline Deep & a) well-structured knowledge base \\
& b) appropriate motivational context \\
& c) learning activity \\
d) interaction between the students and the teacher & a) high workload \\
b) high number of contact hours in class \\
c) excessive amount of course material \\
d) loss of opportunity to explore in-depth content \\
e) gaps in the choice of objects of study and failure to adopt study methods \\
f) an evaluation system that causes fear and anxiety
\end{tabular}

Source: Adapted from Ellis et al. (2008) and Gibbs (1992 apud Kember et al., 2008). 
Table 2. Engagement culture of students in each field of knowledge.

\begin{tabular}{|c|c|c|c|}
\hline Field & Engagement is promoted by & Weaknesses & $\begin{array}{c}\text { Ways to promote it } \\
\text { engagement }\end{array}$ \\
\hline $\begin{array}{l}\text { Natural Sciences and } \\
\text { Engineering }\end{array}$ & $\begin{array}{l}\text { - Understanding based on } \\
\text { quantitative rationality } \\
\text { - Collaborative study } \\
\text { - Performance in technical } \\
\text { components }\end{array}$ & $\begin{array}{l}\text { - Reward for carrying out the } \\
\text { required activities (not for } \\
\text { creativity) } \\
\text { - Low initiative outside the } \\
\text { required activities } \\
\text { - Low interest in connecting } \\
\text { ideas } \\
\text { - Low interaction between } \\
\text { teachers and students }\end{array}$ & $\begin{array}{l}\text { Encourage: } \\
\text { - Class interaction } \\
\text { - Collaborative work } \\
\text { activities } \\
\text { - Presentations, debates and } \\
\text { discussions }\end{array}$ \\
\hline $\begin{array}{l}\text { Social Sciences and } \\
\text { Humanities }\end{array}$ & $\begin{array}{l}\text { - Understanding based } \\
\text { on expression and } \\
\text { interpretation } \\
\text { - Interest in the idea (greater } \\
\text { than in its application) } \\
\text { - Oral sharing on the } \\
\text { interpretations observed in } \\
\text { a topic } \\
\text { - Interaction and discussion }\end{array}$ & $\begin{array}{l}\text { Reward students: } \\
\text { - By verbal aptitude (less by } \\
\text { depth of study) } \\
\text { - Do more than required } \\
\text { because of the interest in } \\
\text { the subject }\end{array}$ & $\begin{array}{l}\text { Encourage collaborative } \\
\text { learning }\end{array}$ \\
\hline
\end{tabular}

Source: Brint et al. (2008, p. 398).

For Jackson et al. (2006) a student freshman can be seen as someone who seeks to appropriate the discourse of a community (teachers, staff, and students). It is expected that, during their academic life, students will acquire technical and behavioural skills necessary for their professional practice. As teaching is structured from a general perspective which aims to give equal treatment to all students who enter the education system, the development of these skills occurs within curricular disciplines and educational and social contexts that permeate teaching practices, such as: teacher and/or student-based, classroom lessons, distance learning, problem solving, project development, experiences. Conclusion has been reached that at first students adapt themselves to the community and to the inducement to which they are exposed.

Studies (March \& Gaffney, 2010; Dym, 2004; Lang et al., 1999) propose to develop collaborative teams in the learning processes.

The National Survey of Student Engagement (NSSE), conducted by Brint et al. (2008, p. 384), presents three aspects that can promote students' engagement in the learning process, particularly aligned with the topic discussed in this paper:

(1) Active Collaborative Learning focuses on practices that encourage students to become more involved in their education. These practices conduct class questions and contribute to a class discussion, making presentations, working in teams on projects during a class, working with other students outside the classroom context, discussing and reading ideas;

(2) Student-College Interaction focuses on the exchange of experiences, which allow students to perceive how specialist teachers solve problems. These experiences include discussing activities, talking about career plans, discussing ideas, and receiving performance feedback from teachers;

(3) Academic challenges focus on experiences, which promote high levels of academic achievement. These experiences include class preparation time, working to reach teachers' expectations, the amount of reading and writing tasks, courses that emphasize the analysis and an index of course material, the application of theories and concepts to real problems.

The NSSE affirm that the benefits promoted by such aspects are: the creation of a study community sense, study discipline, autonomy of the student, articulation of own ideas, possibility to learn with content created collectively, elaboration of models through questions and responses, respect for research and its application in real situations (Brint et al., 2008, p. 384).

Learning can be understood as a (re)construction of knowledge by the student. During this process, besides apprehending the contents that are the object of their learning efforts, students establish relationships and logics that are unique to them. Learning involves a construction of knowledge, requiring students to 
actively create meaning for their own experiences by relating new information with what they already know. Qualified reading and discussion contribute to stimulating the development of skills.

\section{Methodology}

This article analyses a teaching strategy to stimulate reading and the discussion of texts in order to develop skills in Engineering students, based on the Cumbuca Method created by Campos (2004). The research was conducted in the discipline of Production Management, taught in the $5^{\text {th }}$ Year of undergraduate courses at a public school of engineering in the Sao Paulo State by the authors, who proposed the use of the Cumbuca Method as strategy to improve students reading, and three faculty members, who have been teaching the discipline during the last two years. It involved a sample of 200 undergraduates from the Electrical Engineering, Materials Engineering and Mechanical Engineering courses.

This research has a qualitative approach, presenting the following characteristics: the source of the data is the natural environment; the research is descriptive; the analysis of the data tends to occur inductively; the meaning is of fundamental importance for the research. Data collection was based on a semi-structured questionnaire and brainstorming with the students of the Operations Management discipline.

The questions were asked in two groups, those of "introduction", which aimed to warm up the discussion, and the "main" ones concerning the Method. The guiding questions in their order of application were:

- What are the strengths of the discipline? (Issue of introduction);

- What are the opportunities of the discipline? (Issue of introduction);

- What are the opportunities of the Method? (Main research question);

- What are the strengths of the Method? (Main research question).

The consolidated responses of each class were discussed with the students in the classroom. The entire script was done in the last class of the course. After this stage, the teachers of the discipline discussed the answers among themselves.

Learning occurs through interaction with nature and the symbols we use to structure and represent it (Winsor, 1990). Among these representations, the academy uses articles and books supplied by academic industry. The importance of encouraging reading is undeniable for student learning. Making it a habit is a challenge. Engineering courses usually fail in this challenge and this influences the training of the skills and abilities of the graduates.

Educators have the responsibility of helping students navigate through difficult situations and negotiate the consequences of their actions, allowing them to examine and reflect on the decisions made. Students are engaged in dynamic and interactive networks with their peers, families and educators, all of which are influenced by community contexts.

Campos (2004) created the Cumbuca Method for implementing Quality Management Systems in organizations and the maturation of their concepts among employees, through the stimulation of reading, studying and the regular process of group discussion in that environment. Several companies have used this method for several years.

The popularity of the Method in the corporate environment aroused the interest in creating similar conditions for its application in the Production Management classes. To do so, it has been adapted to the following steps and recommendations:

1. Definition of the schedule of classes, topics and articles to be discussed in each class. This is displayed on the first day of the term. It is highly recommended that:

a) All of the articles are made available to students on the first day of school;

b) The meetings are frequent, weekly meetings are suggested. Bi-weekly experiments do not produce good results because of a breach in the routine.

2. Every week the name of a student is drawn at the beginning of class to present the article that has been scheduled for then.

a) The student has to have prepared his own support material based on the article studied, usually a slide presentation and/or some audio-visual resource for a 20-30 minute long presentation. However, with class engagement, presentation time may increase;

b) At the beginning of the class one student is drawn and he need to expresses readiness or not. The drawing of names is made from the students who are prepared. If the presenter is not prepared and only reveals this after having been drawn, the meeting is cancelled by assigning a Zero to the group. One should not draw or indicate another name nor accept volunteers to make the presentation. The method is based on everyone's commitment to the group; 
c) As provided by the bylaws of the institution, students are allowed $30 \%$ of absences during the school year; thus, the criterion is to take advantage of the 4 best grades of a total of 6 presentations, or about $70 \%$ of the best grades;

d) It was observed that classes with more than 30 students obstruct the class dynamics proposed;

e) Due to the randomness of the student chosen in the draw, the student who presents an article in a week may be drawn again in the following weeks.

3. A second student is drawn to report the main points of the discussion held in class. As, in principle, all of them students studied to make their presentations, the discussion is generally rich and new points appear in relation to the article alone. This report is delivered 5 minutes after the end of the meeting, i.e. it is not to be written or generate extra-class effort.

a) Due to the randomness of the student chosen in the draw, the student who reports the main points in a week may be drawn again in the following week.

4. At the end of the meeting the teacher gives the students feedback on the positive points and on the improvement. Opportunities identified in the class dynamics of the day. This is done through constructive dialogue with the class.

The learning process promoted by the Method is based on the students preparing the presentation of the article beforehand. Savander-Ranne et al. (2008) indicate the importance of pre-class preparation to strengthen class dynamics, based on previous knowledge and the link between theory and the practical discussion presented in class.

Palmer et al. (2008, p. 851) advocate the valuation of participation within limits of control as mandated so that student motivation engenders a high level of participation and discussion. These authors indicate that students' resistance to extra class activities is common, and this can be minimized by activity assessments. In the Method adopted, the students' assessment is guided by the following criteria:

a) Presentation (2 points) is observed with respect to the preparation of the student regarding the content studied, the presentation of the arguments, an initiative to stimulate constructive discussion among the participants, complementary examples to illustrate the argument presented on the article, critical attitude;

b) Group discussion (2 points) that includes the participation of the other students, which also allows those who declare themselves unprepared to participate;

c) Presentation (1 point) reflects the quality of the support material presented. This includes the organization of the arguments in the support material, creativity in preparing the slides, insertion of additional audiovisual resources;

d) Report (1 point) which records the additional issues discussed in the room and which were not in the original article.

Note that the dynamics between criteria a) and b) are interactive and can stimulate different outcomes. A shy person can acquire resourcefulness with the support of the other participants and also the participants can be stimulated by the thought provoking questions made by the presenter.

The final feedback is intended to record the strengths of the dynamics of the day and indicate improvements. This encourages the development of other skills and competences beyond content learning, such as critical analysis, constructive feedback, and self-criticism. Hwang \& Chang (2011) show the importance of immediate feedback for a better reflection, critical analysis and identification of improvement opportunities. It is ideal, after the students are familiar with the method, that they also indicate the positive aspects and opportunities for improvement, which allows for a maturation of the event and the group's ability to critically analyze the answers (class by class). Of course, due to the impact on the grade, students often have a tendency to overvalue the positive points and minimize the opportunities for improvement. It is the teacher's role to mediate this situation.

\section{Findings and discussion}

In their responses, highlighted in italics, the students indicated favourable (positive) or unfavourable (opportunity) perceptions for a single characteristic of the Method. In this sense, the analysis of the answers is discussed by identifying the issues associated with their characteristics. The following responses, relating to the "time" characteristic, illustrate such different perceptions:

\section{It ensures that everyone arrives on time.}

We ask for greater tolerance with the available time. 
In the first response, the student highlights this characteristic as a Positive Point of the Method. The second is associated with an Opportunity for Improvement.

The following answers suggest that the students considered the Production Management classes as being dynamic, relaxed, rich in examples close to the corporate reality, many of which were brought by the students themselves, with a multidisciplinary approach to industrial issues that are considered interesting. This may have happened because the students are undertaking internships in companies. Interactivity among students, discussion involving different points of view, engagement of the class in reading the articles, and responsibility towards the other classmates is also observed.

It helps us make sense of the theory.

The classes are more dynamic and relaxed with student interactivity.

It motivates us to study every week and to get to know the subject of the next class.

it encourages us to read regularly.

Interesting articles.

All of the students read the articles.

There is great integration of the students.

Ideas are stimulated in relation to the daily life of the company.

There is an application of knowledge to practice.

It improves responsibility towards being prepared for class.

The performance of the discipline improves because the workload actually increases.

In their responses, students indicated improvement in their: oral communication, ability to prepare supporting material (slides), reading and learning, interaction with the rest of the group through questions and contributions of examples, time management. These are the skills and abilities expected from engineering undergraduates (Dym, 2004, p. 50; Mohan et al., 2010; Montero \& González, 2009; Zainaghi et al., 2001). It is also believed that, in general, these characteristics are positively highlighted due to the absence of this type of stimulus in other disciplines. As anticipated, some students realized that the Method helps them to study regularly, lessening the traditional effort on the eve of exams. The engagement of the students benefited from the contribution of the grade obtained by the Method in the bimonthly grades, as indicated by Palmer et al. (2008, p. 851).

The students made critical remarks concerning the use of articles that they considered extensive and/or were written in English, the weekly frequency of presentations, the randomness of choice of the presenter, the exams, lack of timeliness to begin drawing the name of the presenter, as shown by the following responses:

Please take out the long texts to read at home. Because we are in the $5^{T H}$ Year we do not have much time to read them.

There should be more texts in Portuguese.

Do not repeat the student who has already presented.

Draw names without substitution for seminars.

Determine groups to make the presentations.

The seminars should be divided by groups.

The people of the seminars should be previously defined instead of drawing names.

The evaluation of a single student should not affect the grades of the others.

With regard to these responses, it should be emphasized that articles should be provided to students in their first class, which allows them to plan and organize the time for presentation during the term. Many students did.

There is an incidence of student indications that the distribution of the articles should be done by groups of students previously defined at the beginning of the course. The teachers said that according to their experience usually only the presenters prepare themselves for giving a presentation on the topic, a fact that does not promote collective participation and eliminates the aspect of regular commitment to studying the topic. Still with respect to the answers associated to the group presentation, it is believed that the randomness of the selection among the students who are prepared values the responsibility of each student towards the group. As previously noted, the participation of the other classmates during the presentation promotes an interactive process.

The following answer shows that although some students consider the texts lengthy, especially those from periodicals, the majority has realized the importance of the teaching strategy used and has managed their time to carry out the task, which corresponds to an important professional skill.

I fully agree with the fact that many of the classes sound more like monologues than an actual class and that learning is not effective when information is thrown at the students instead of them being motivated by the teacher. I believe that seminars can create curiosity and increase the amount of time students spend reading and that the lack of reading is a FACT among the engineering students.

From the critical remarks made by the students, the teachers who used the method declared that in the 
first classes a greater amount of articles of national congresses, that are short and in Portuguese, should be used. They suggested starting with articles presented at the congresses of the field (ENEGEP, SIMPOI, SIMPEP) and moving towards those published in good international journals, still in the first two months. The use of articles in the English language should be measured during the academic period and would aim to increase vocabulary and technical jargon generally explored in the dynamics of contracting and the professional activity.

There are students who still read the article and prepare their presentations on the eve of class. It is striking that some students indicate this as a positive point:

\section{Agility to do work in a short period of time.}

The teachers observed a greater involvement on the part of the students when recent articles were included, relating the content of the subject to the area of student training, for example, Strategy in the area of Energy (Electrical Engineering), Quality Management in Steel (Materials Engineering) Automotive Product Development (Mechanical Engineering). They also observed the importance of carrying out the discussion of the article at the beginning of the class in order to avoid dispersion of the students due to the preparation of the material or understanding of the article during the course of the class itself.

With respect to the characteristic associated with the exercise of argumentation, exposition and debate on a given topic, the students indicated the development of these abilities and skills as a positive point. Many of them still expected teacher-based participation during the seminar. Some students suggested that the teacher should raise questions, but that this stage of the class should continue to be led by the students in order to develop the skills and abilities expected.

Promotes Interaction / Speech Learning.

Debates and discussions - different points of view.

Stimulates oral presentations.

Opportunities for improvement in preparing the slides for the presentation.

The content should be delivered by the teacher.

In these answers, the students pointed out the importance of the discussion among the classmates during the course, as well as the skills and abilities associated with oral presentation.

Some students suggested that the teacher should briefly introduce the concepts related to the seminar before its beginning, in order to reduce the anxiety associated with the presentation of the seminar. It is believed that the students should research, ask questions and be challenged to prepare for the seminar. One may, however, anticipate some of the issues in the class prior to the respective seminar, doing so will help create a proactive environment for applying the Method.

[...] the Cumbuca Method makes us feel as anxious as a test does because it has the weight of an evaluation [...].

Less pressure on students to prepare the presentations [...].

With regard to the contribution of the discussion of the texts in the bimonthly grades, it is important that the teacher promote student commitment, both individual and collective, for its accomplishment (Palmer et al., 2008). It is observed that the fact that the test has a greater weight is less questioned by the students due to the evaluation model to which that they are accustomed. It is suggested a greater weight be arbitrated to the individual test, for example $60 \%$ for the test and $40 \%$ for the seminar as a starting point. Some students indicate this as a positive trait. In this sense, some students were indicated to maintain the exclusivity of individual tests as evaluation, while others suggested eliminating the tests, using as evaluation only the presentations based on the Method.

\section{[...] Exchange exams for papers [...] Assign papers instead of giving exams.}

Decrease the weight of articles / The content of the articles should not be tested in the exams.

Presentations should be worth extra grades instead of being discounted from the grades.

It helps our grades and helps us study for exams.

It makes students study.

[...] if it is to enhance the apprehension of knowledge, the quality of teaching, I believe that only conducting seminars and case studies is enough.

The contents addressed in the seminars should not be assessed in the exams.

Students considered it unnecessary to include questions from the articles in the individual tests. This characteristic has two aspects: the first is favourable to the claim because if there is engagement, participation and dedication in the preparation of the seminars, commitment to the activity and assimilation of the subject is evidenced; the second is that students want to reduce their study load on the eve of exams, still a common habit. Teachers have the autonomy to balance those aspects and share their perception and decision with the students.

The adherence to the Method is not unanimous among teachers of other disciplines and students, but the results analysed in recent years indicate that regardless of the criticism pointed out, it contributes to the development of skills and abilities beyond content learning. 


\section{Conclusion}

The results of this research indicate that, in addition to improving student learning, there is improvement in their engagement in the act of learning. Although the exposition of the subject is led by only one of the students in a given stage of the class, the fact that the other students have read the articles before the class incites debate and collective participation, motivates and stimulates the degree of interest in the content of the discipline, improves reading habits, and results in an enlargement of the students' technical/scientific repertoire, reduces the number of monologues and the expository character of teacher-based classes.

In this sense, this research evidenced that the Cumbuca Method, as an Engineering Teaching strategy, stimulated regular reading and debate among students, which may have allowed the development of skills and abilities associated with oral communication, and the organization and presentation of seminars, in addition to expanding the content discussed in class.

The literature indicates that the learning process can be improved by lesson planning and teaching strategies used by the teacher, as well as indicates that students seek to create meaning for their own experiences by relating new information to what they already know.

Lujan \& DiCarlo (2006) and Powell (2003) indicate that the use of new technologies contributes to the learning process. However, well-planned processes like the Cumbuca Method can also contribute to such a process.

It is suggested that further research should be conducted to evaluate the Method applying the procedure indicated by Mohan et al. (2010) to subjects of other Engineering courses and should be validated by a larger sample size of courses and respondents.

\section{Acknowledgements}

We would like to thanks Prof. Maurício C. Delamaro for Cumbuca Method start-up to the Engineering students.

\section{References}

Brint, S., Cantwell, A. M., \& Hanneman, R. A. (2008). The two cultures of undergraduate academic engagement. Research in Higher Education, 49(5), 383-402. http:// dx.doi.org/10.1007/s11162-008-9090-y.

Campos, V. F. (2004). TQC: controle da qualidade total (no estilo japonês). Belo Horizonte: Instituto Nacional de Desenvolvimento Gerencial.

Chubin, D., Donaldson, K., Olds, B., \& Fleming, L. (2008). Education generation net can U.S. engineering woo and win the competition for talent? Journal of Engineering Education, 97(3), 245-257. http://dx.doi. org/10.1002/j.2168-9830.2008.tb00977.x.
Delamaro, M. C., Migroni, A., \& Cicone, D. (2006). Sobre hábitos de leitura de estudantes de Engenharia: um estudo preliminar. In Anais do Congresso Brasileiro de Ensino (COBENGE) (p. 1-15). Passo Fundo: COBENGE. Retrieved in 2013, December 13, from http://www.dee. ufma.br/ fsouza/anais/arquivos/9_256_304.pdf

Dym, C. L. (2004). Design, systems, and engineering education. International Journal of Engineering Education, 20(3), 305-312.

Ellis, R. A., Goodyear, P., Calvo, R. A., \& Prosser, M. (2008). Engineering students' conceptions of and approaches to learning through discussions in face-to-face and online contexts. Learning and Instruction, 18(3), 267-282. http://dx.doi.org/10.1016/j.learninstruc.2007.06.001.

Hissey, T. W. (2000). Education and careers 2000: enhanced skills for engineers. Proceedings of the IEEE, 88(8), 1367-1370. http://dx.doi.org/10.1109/5.880089.

Hwang, G., \& Chang, H. (2011). A Formative assessmentbased mobile learning approach to improving the learning atitudes and achivements of students. Computer Education, 56(4), 1023-1031. http://dx.doi.org/10.1016/j. compedu.2010.12.002.

Jackson, L., Meyer, W., \& Parkinson, J. (2006). A study of the writing tasks and reading assigned to undergraduate science students at a South African university. English for Specific Purposes, 25(3), 260-281. http://dx.doi. org/10.1016/j.esp.2005.04.003.

Kember, D., Leung, D. P., \& McNaught, C. (2008). A workshop activity to demonstrate that approaches to learning are influenced by the teaching and learning environment. Active Learning in Higher Education, 9(1), 43-56. http://dx.doi.org/10.1177/1469787407086745.

Lamancusa, J. S., Zayas, J. L., Soyster, A. L., Morell, L., \& Jorgensen, J. (2008). The learning factory: industrypartnered active learning. Journal of Engineering Education, 97(1), 1-15.

Lang, J. D., Cruse, S., McVey, F. D., \& McMasters, J. (1999). Industry Expectations of new engineers: a survey to assist curriculum designers. Journal of Engineering Education, 88(1), 43-51. http://dx.doi. org/10.1002/j.2168-9830.1999.tb00410.x.

Lujan, H. L., \& DiCarlo, S. E. (2006). Too much teaching, not enough Learning: what is the soluction? Advances in Psychology Education, 30(1), 17-22. PMid:16481604.

March, E., \& Gaffney, J. S. (2010). Relational identities of students, families, and educators. Remedial and Special Education, 31(1), 3-16. http://dx.doi. org/10.1177/0741932508324393.

Martin, R., Maytham, B., Case, J., \& Fraser, D. (2005). 'Engineering graduates' perceptions of how well they were prepared for work in industry. European Journal of Engineering Education, 30(2), 167-180. http://dx.doi. org/10.1080/03043790500087571. 
McMasters, J. H. (2006). Influencing student learning: an industry perspective. International Journal of Engineering Education, 23(3), 447-459.

Mohan, A., Merle, D., Jackson, C., Lannin, J., \& Nair, S. S. (2010). Professional skills in the engineering curriculum. IEEE Transactions on Education, 53(4), 562-571. http://dx.doi.org/10.1109/TE.2009.2033041.

Montero, E., \& González, M. J. (2009). Student engagement in a structured problem-based approach to learning: a first-year eletronic engineering study module on heat transfer. IEEE Transactions on Education, 52(2), 214221. http://dx.doi.org/10.1109/TE.2008.924219.

Palmer, S., Holt, D., \& Bray, S. (2008). Does the discussion help? The impact of a formally assessed online discussion on final student results. British Journal of Educational Technology, 39(5), 847-858. http://dx.doi. org/10.1111/j.1467-8535.2007.00780.x.

Pister, K. S. (1993). A context for change in engineering. Journal of Engineering Education, 82(2), 66-69. http:// dx.doi.org/10.1002/j.2168-9830.1993.tb00078.x.

Powell, K. (2003). Science education: spare me the lecture. Nature, 425(6955), 234-236. PMid:13679886. http:// dx.doi.org/10.1038/425234a.

Riley, L. A., Furth, P. M., \& Zellmer, J. T. (2000). Assessing our engineering alumni: determinants of success in the workplace In 2000 ASEE/Gulf-Southwest Section Annual Conference. Las Cruces: ASEE.

Sageev, P., \& Romanowski, C. J. (2001). Message from recent engineering graduates in the workplace: results of a survey on technical communication skills. Journal of Engineering Education, 90(4), 685-693. http://dx.doi. org/10.1002/j.2168-9830.2001.tb00660.x.

Savander-Ranne, C., Lundén, O., \& Kolari, S. (2008). An alternative teaching method for electrical engineering courses. IEEE Transactions on Education, 51(4), 423431. http://dx.doi.org/10.1109/TE.2007.912500.

Winsor, D. A. (1990). Engineering writing/writing engineering. College Composition and Communication, 41(1), 58-70. http://dx.doi.org/10.2307/357883.

Zainaghi, G., Akamine, E. G., \& Bremer, C. F. (2001). Análise do perfil profissional do engenheiro de produção adquirido nas atividades extracurriculares. In Anais do $29^{\circ}$ Congresso Brasileiro de Ensino de Engenharia (COBENGE). Brasília: ABENGE.

Zhou, C. (2012). Fostering creative engineers: a key to face the complexity of engineering practice. European Journal of Engineering Education, 37(4), 343-353. http:// dx.doi.org/10.1080/03043797.2012.691872. 